\title{
ÁAirman
}

Jurnal Teknik dan Keselamatan Transportasi

\section{Kompetensi Sosial Pendidik dan Pengasuh dalam Membangun Keunggulan Taruna di Politeknik Penerbangan Makassar}

\section{Social Competence of Educators and Tutors in Building Cadet Excellence at Politeknik Penerbangan Makassar}

\author{
Ahmad Bahrawi ${ }^{1}$, Nining Idyaningsih ${ }^{2}$ \\ ahmad.bahrawi@poltekbangmakassar.ac.id, ondeng77@gmail.com \\ Politeknik Penerbangan Makassar
}

\begin{abstract}
ABSTRAK
Tujuan dari penelitian ini adalah mendeskripsikan kompetensi sosial pendidik dan pengasuh dalam membangun keunggulan taruna di politeknik penerbangan makassar. Penelitian ini adalah penelitian kualitatif, case study design. Teknik pengumpulan data menggunakan wawancara, observasi, dan dokumentasi. Data yang diperoleh dianalisis menggunakan teknik analisis deskriptif kualitatif yang dilakukan secara interaktif. Hasil dari penelitian ini yaitu: kompetensi sosial pendidik dan pengasuh diwujudkan dalam tiga bentuk yaitu kerjasama, partisipasi, dan kepekaan. Kompetensi sosial pendidik dan pengasuh pertama yaitu adanya kerjasama dan koordinasi yang baik antar sesama maupun kepada pimpinan. Selanjutnya, pendidik dan pengasuh berpartisipasi aktif dengan terjun langsung membina dan mengembangkan Taruna baik secara akademik maupun non akademik. Kepekaan dan kepedulian pendidik dan pengasuh dibuktikan dengan adanya perbedaan pola pengasuhan, variasi metode belajar, tugas secara individu, serta penilaian yang objektif dan tidak diskriminatif.
\end{abstract}

Kata kunci: kompetensi sosial; pendidik; pengasuh

\begin{abstract}
This study aims to describe the social competence of educators and tutors in building cadet excellence in the makassar aviation polytechnic. This research is qualitative research with a case study approach. Data collection techniques used are interviews, observations, and documentation. The data obtained is then analyzed using qualitative descriptive analysis techniques conducted interactively. The results of this study are: the social competence of educators and tutors is realized in three forms, namely cooperation, participation, and sensitivity. The social competence of educators and tutors are the existence of good cooperation and coordination between each other and to the leadership. Furthermore, educators and caregivers actively participate by directly fostering and developing Cadets both academically and non-academically. The sensitivity and care of educators and tutors is evidenced by differences in parenting patterns, variations in learning methods, individual tasks, and objective and non-discriminatory assessments.
\end{abstract}

Keywords: social competency; educator; tutor 


\section{PENDAHULUAN}

\section{Politeknik Penerbangan Makassar} (Poltekbang Makassar) merupakan Unit Pelaksana Teknis (UPT) dibawah Kementerian Perhubungan yang diberikan tanggung jawab untuk menyelenggarakan Pendidikan dan Pelatihan (Diklat) di bidang Penerbangan. Selain sebagai lembaga Diklat, Poltekbang Makassar juga merupakan perguruan tinggi vokasi yang menyelenggarakan pendidikan, penelitian, dan pengabdian kepada masyarakat di bidang transportasi udara. Berdasarkan Peraturan Menteri Perhubungan Nomor 48 tahun 2019, Poltekbang Makassar memiliki empat program studi jenjang diploma tiga yaitu: Manajemen Lalu Lintas Udara (MLLU), Teknologi Navigasi Udara (TNU), Teknologi Bandar Udara (TBU), dan Teknologi Pemeliharaan Pesawat Udara (TPPU). Poltekbang Makassar memiliki tujuan utama menghasilkan lulusan yang berkualitas, kompeten, serta dapat bersaing dalam kancah nasional maupun global.

Poltekbang Makassar memiliki sistem boarding school dalam pelaksanaan pendidikannya. Berdasarkan Peraturan Kepala Badan Pengembangan SDM Perhubungan Nomor PK. 02/BPSDMP-2018 pembangunan karakter SDM transportasi perlu dilaksanakan secara terpadu, terstruktur, terencana, berjenjang, dan dengan metode yang tepat. Oleh sebab itu, sistem boarding school dipilih karena sistem pendidikan yang dapat dilaksanakan hingga 24 jam. Menurut Octavia, dkk (2014) boarding school merupakan sistem pendidikan 24 jam dimana peserta didik dikondisikan dalam kamar-kamar sehingga mempermudah dalam pengaplikasian sistem pendidikan yang total. Sistem pendidikan yang berlangsung selama 24 jam dilaksanakan oleh Pendidik yang bertugas di kelas selama jam akademik dan Pengasuh yang bertanggung jawab terhadap kegiatan taruna diluar jam akademik.

Pendidik dan Pengasuh merupakan dua pihak yang berinteraksi langsung dengan taruna selama melaksanakan pendidikannya. pendidik merupakan Dosen, Instruktur, dan/atau Konselor yang bertanggung jawab terhadap pengajaran dan pembelajaran taruna selama jam akademik baik di ruangan kelas maupun di ruangan praktik. Berbeda dengan Pendidik, Pengasuh merupakan Pegawai tetap/kontrak dan/atau anggota Angkatan Udara Tentara Nasional
Indonesia atau biasa disebut AURI yang diberikan wewenang dan tanggung jawab untuk membina dan memantau perkembangan taruna berdasarkan surat keputusan Direktur Poltekbang Makassar. Pengasuh AURI merupakan kerjasama Poltekbang Makassar dengan TNI-AU dengan tujuan membina fisik dan mental taruna agar dapat mencapai keunggulan dalam bidangnya masing-masing tanpa mengabaikan perkembangan aspek akademiknya. Walaupun keduanya memiliki perbedaan peran, baik Pengajar maupun Pengasuh memiliki tanggung jawab yang sama sebagai agen pendidik taruna selama menempuh studinya di Poltekbang Makassar. Menurut Permenristekdikti Nomor 44 Tahun 2015 tentang Standar Nasional Pendidikan Tinggi, Pendidik memiliki lima kompetensi yang harus dikuasai, yaitu: Kompetensi Kepribadian, Kompetensi Manajerial, Kompetensi Akademik, Kompetensi Penelitian dan Pengembangan, serta Kompetensi Sosial.

Menurut Hurlock dalam Krismastyanti (2009) kompetensi sosial merupakan kemampuan seseorang untuk berhubungan dengan orang lain serta terlibat dalam situasisituasi sosial. Berdasarkan hal tersebut, kompetensi sosial menjadi kemampuan penting bagi seorang yang memiliki tanggung jawab untuk mendidik sebuah lembaga/kelompok. Kompetensi sosial dalam bidang pendidikan berkaitan erat dengan proses pengajaran dan pembelajaran antara pendidik dan peserta didik. menurut Adnan (2015) kompetensi sosial adalah kompetensi yang mencakup kemampuan berkomunikasi, kemampuan bergaul dengan peserta didik, sesama pendidik dan tenaga kependidikan, orang tua/wali peserta didik dan masyarakat sehingga dapat memberikan dukungan yang cukup baik dalam bentuk keterampilan sosial pendidik. Kompetensi sosial harus dimiliki seorang pendidik dikarenakan agar pendidik dapat menjalin hubungan yang baik dengan orang yang akan dididiknya (Idyaningish, 2019).

Kompetensi sosial dalam bidang pendidikan tercantum dalam Permendiknas Nomor 13 Tahun 2007 tentang standar kepala sekolah. Indikator kompetensi sosial menurut Permendiknas diatas meliputi: 1) bekerjasama dengan pihak lain untuk kepentingan sekolah, 2) berpartisipasi dalam kegiatan sosial 
kemasyarakatan, dan 3) memiliki kepekaan sosial terhadap orang atau kelompok lain. Oleh karena itu, Kompetensi sosial dalam bidang pendidikan dapat diukur melalui tiga indikator, yaitu kerjasama, partisipasi, dan kepekaan. Adanya kompetensi sosial yang dimiliki oleh setiap pendidik dan pengasuh di Poltekbang Makassar akan membentuk budaya serta lingkungan belajar yang positif dan saling mendukung guna menciptakan keunggulan taruna sesuai ciri khasnya masing-masing.

\section{METODE}

Penelitian ini merupakan penelitian kualitatif. Menurut Lexy J. Moleong (2012) penelitian kualitatif adalah penelitian yang bertujuan untuk memahami fenomena tentang apa yang dialami subjek penelitian secara holistic dan dideskripsikan dalam bentuk kata dan bahasa dengan konteks dan metode yang alamiah. Penelitian ini mendeskripsikan aspekaspek secara holistik terkait kompetensi sosial pendidik dan pengasuh dalam rangka membangun keunggulan taruna.

Penelitian ini menggunakan pendekatan studi kasus yang merupakan metode riset yang menggunakan berbagai sumber data untuk meneliti, menguraikan, dan menjelaskan secara komprehensif dan sistematis (Rachmat, 2006). Sejalan dengan pendapat tersebut, menurut Yin (2011) studi kasus merupakan metode yang mengacu pada penelitian yang mempunyai unsur how dan why pada pertanyaan utama penelitiannya serta fokus pada masalah-masalah actual yang ada di kehidupan nyata. Oleh karena itu, penelitian ini berusaha mengungkap indikator kompetensi sosial yang dimunculkan oleh pendidik dan pengasuh dalam bentuk kerjasama, partisipasi, dan kepekaan dalam rangka membangun keunggulan taruna di Poltekbang Makassar.

Teknik pemilihan informan dalam penelitian ini menggunakan purposive sampling yaitu pemilihan subjek atau informan dengan pertimbangan tertentu (Sugiyono, 2016). Subjek penelitian ini berasal dari pendidik dan pengasuh yang aktif di Poltekbang Makassar. Sumber data dalam penelitian ini terdiri data data primer dan data sekunder. Menurut Robert K. Yin (2011) terdapat enam jenis sumber data yang bisa digunakan dalam penelitian kulitatif, yaitu: dokumen, rekaman, arsip, wawancara, observasi langsung, observasi pemeran, dan perangkat fisik.

Metode pengumpulan data yang digunakan dalam penelitian ini yaitu observasi, dokumentasi, dan wawancara. Data yang telah dikumpulkan selanjutnya akan dianalisis menggunakan teknik interactive model data analysis. Analisis data dilakukan secara interaktif dan berlangsung terus menerus sampai tuntas, sehingga datanya jenuh. Interactive model data analysis yang dimaksud menurut Miles dan Huberman (dalam M.Djamal 2015) terdiri dari tiga langkah interaktif yaitu reduksi data, penyajian data, dan penarikan kesimpulan yang dapat digambarkan sebagai berikut:

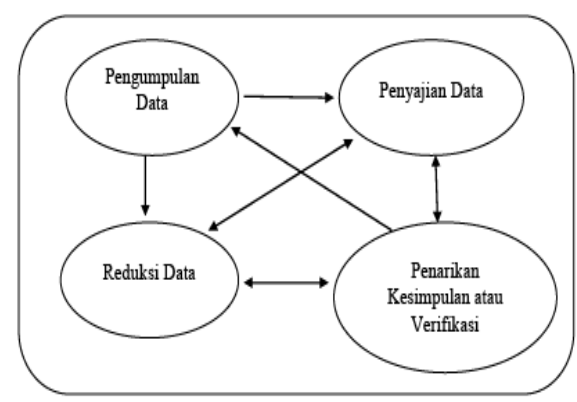

Gambar 1. Interactive Model Data Analysis Sumber: Miles dan Huberman (dalam M. Djamal 2015)

\section{HASIL DAN PEMBAHASAN}

a. Hasil Penelitian

Hasil observasi dan wawancara terhadap pendidik dan pengasuh menunjukkan bahwa kompetensi sosial ditunjukkan selama melaksanakan tupoksinya masing-masing. kompetensi sosial yang muncul berkaitan erat dengan pelaksanaan tanggung jawab pengajaran dan pembelajaran pendidik serta pengawasan dan pembinaan pengasuh Poltekbang Makassar. Pertama, hasil wawancara dan observasi yang dilaksanakan menunjukkan bahwa telah terjalin kerjasama yang baik antara pendidik dan pengasuh. Hal tersebut dibuktikan dengan adanya penyampaian informasi yang diperlukan saat pergantian piket serta koordinasi untuk mengatasi kendala yang dihadapi. Koordinasi yang dibangun secara efektif antar sesama pendidik dan pengasuh ataupun dengan pimpinan dibangun guna menemukan solusi terbaik dari kendala yang dihadapi.

Selanjutnya, hasil wawancara dan observasi terhadap pendidik dan pengasuh menunjukkan bahwa adanya partisipasi 
langsung dalam pengembangan diri taruna secara akademik maupun non akademik. pendidik berupaya semaksimal mungkin untuk selalu membangun interaksi yang intens bersama taruna, serta memperhatikan sikap dan kedisiplinan taruna selama mengikuti pembelajaran. Partisipasi pengasuh dalam upaya membangun keunggulan taruna diwujudkan dalam pemanfaatan waktu diluar jam akademik untuk melakukan pembinaan terhadap fisik dan mental taruna. Terakhir, indikator kompetensi sosial yaitu kepekaan. Baik pendidik maupun pengasuh menunjukkan kepekaan dan kepedulian terhadap perkembangan taruna dengan adanya perbedaan pola pengasuhan, variasi metode pembelajaran, penugasan individu, serta penilain yang bersifat objektif dan tidak diskriminatif.

\section{b. Pembahasan}

Kompetensi sosial pendidik dan pengasuh memiliki peran penting dalam membangun keunggulan taruna. Pendidik dan Pengasuh di Poltekbang Makassar dalam pelaksanaan tupoksinya menunjukkan tiga indikator dari kompetensi sosial dalam bidang pendidikan yaitu: kerjasama, partisipasi, dan kepekaan. Kompetensi sosial yang dimiliki membantu pendidik dan pengasuh meningkatkan kinerjanya dalam pembinaan dan pengembangan diri taruna. hal tersebut sejalan dengan hasil penelitian yang dilaksanakan oleh Adnan (2015) yang menunjukkan bahwa kompetensi sosial pendidik berpengaruh terhadap pencapaian kinerja pendidik dalam proses pembelajaran dan peningkatan prestasi belajar peserta didik. Oleh karena itu, dapat disimpulkan bahwa kompetensi sosial pendidik dan pengasuh juga berperan dalam membangun keunggulan taruna di Poltekbang Makassar.

Poltekbang Makassar dengan penerapan boarding school sebagai metode pendidikannya memiliki keunggulan tersendiri dibandingkan perguruan tinggi pada umumnya. Sistem Boarding school yang diberlakukan menyebabkan pembelajaran tidak hanya berlangsung pada jam akademik saja. Terdapat pendidik yang bertanggung jawab terhadap pembelajaran taruna pada jam akademik dan pengasuh yang bertanggung jawab terhadap pembelajaran taruna diluar jam akademik. Sejalan dengan hal tersebut, menurut Sholikhun (2018) proses belajar pada lembaga boarding school dilaksanakan melalui pendidikan yang terintegrasi, pembiasaan perilaku, dan percontohan yang baik. Oleh sebab itu, terjalinnya kerjasama yang baik antara pendidik dan pengasuh, membuktikan adanya terintegrasi yang baik dalam hal pengembangan akademik maupun non akademik taruna. Koordinasi antar sesama pendidik dan pengasuh maupun kepada pimpinan bila terdapat kendala yang ditemukan saat menjalankan tugas juga membuktikan bahwa kompetensi sosial pendidik dan pengasuh muncul dalam upaya membangun keunggulan taruna. Hal tersebut sesuai dengan pendapat Hurlock (1980) yang menyatakan bahwa kompetensi sosial adalah kemampuan untuk berhubungan dengan orang lain dan situasi situasi sosial.

Indikator kompetensi sosial berupa partisipasi dalam upaya mewujudkan keunggulan taruna muncul dalam bentuk adanya partisipasi langsung pengasuh dalam pendidikan moral bagi taruna. Menurut hasil penelitian dari Gedviliene et al (2014), menemukan bahwa Kompetensi sosial dalam pendidikan dapat dilihat baik dalam perspektif psikologis maupun sosial. Pengasuh sebagai pihak yang bertanggung jawab terhadap perkembangan taruna diluar jam akademik melakukan pembinaan langsung secara fisik maupun mental kepada taruna. Pembinaan ini dimaksudkan agar perkembangan aspek akademis taruna dapat diimbangi dengan perkembangan dari sisi lainnya juga. Selain pengasuh, partisipasi untuk membentuk keunggulan taruna juga dimunculkan oleh pendidik. Partisipasi pendidik diwujudkan dengan adanya interaksi secara langsung dengan taruna dan selalu memperhatikan sikap dan kedisiplinan taruna. Oleh karena itu, Poltekbang Makassar berupaya untuk selalu membangun lingkungan dan budaya belajar yang kondusif dan mendukung bagi pengembangan keunggulan taruna baik dari sisi akademik maupun non akademiknya.

Pada aspek kepekaan, baik pendidik maupun pengasuh sama-sama memiliki kepekaan dan kepedulian terhadap perkembangan taruna. Hal tersebut diwujudkan dengan adanya perbedaan pola pengasuhan yang diberikan, variasi metode pembelajaran, pemberian tugas secara individu, serta penilaian yang bersifat objektif dan tidak diskriminatif. Menurut Hurlock dalam Krismastyanti, (2009) kompetensi sosial merupakan suatu produk 
kerjasama yang berasal dari dalam diri individu (kognitif, konsep diri, pusat kendali, dan temperamen) dan luar diri individu (interaksi dengan keluarga dan lingkungannya). Diperkuat dengan proses belajar yang diperoleh dalam waktu dan tempat selama individu melalui pengalamannya berinteraksi dengan orang lain. Hal tersebut menunjukkan bahwa adanya kepekaan dan kepedulian yang dibangun oleh pengasuh dan pendidik terhadap perkembangan taruna secara tidak langsung juga merupakan sebuah sarana pembelajaran untuk mengembangkan kompetensi khususnya kompetensi sosial.

\section{KESIMPULAN}

Pendidik dan Pengasuh telah menunjukkan kompetensi sosial dalam rangka membangun keunggulan taruna di Poltekbang Makassar. Kompetensi sosial tersebut diwujudkan dalam tiga bentuk yaitu kerjasama, partisipasi, dan kepekaan. Pendidik dan Pengasuh telah bekerjasama dan berkoordinasi dengan baik baik antar sesama maupun kepada pimpinan. Selanjutnya, Pendidik dan Pengasuh juga telah berpartisipasi aktif dalam meningkatkan keunggulan taruna Poltekbang Makassar dengan terjun langsung membina dan mengembangkan Taruna baik secara akademik maupun non akademik. Terakhir, adanya perbedaan pola pengasuhan, variasi metode belajar, tugas secara individu, serta penilaian yang objektif dan tidak diskriminatif membuktikan bahwa Pendidik dan Pengasuh memiliki kepekaan dan kepedulian terhadap perkembangan Taruna guna mencapai tujuan Poltekbang Makassar.

\section{DAFTAR PUSTAKA}

Adnan Hakim. (2015). Contribution of Competence Teacher (Pedagogical, Personality, Professional Competence and Social) On the Performance of Learning. The International Journal of Engineering and Science (IJES) Vol. 4 No.2 Februari 2015 hal. 01-12.

Idyaningsih, N. . (2019). Parenting Alternative (Education, Coaching and Supervision) Cadet of ATKP Makassar and its Implications for the Personal Resilience of Cadets. Airman: Jurnal Teknik Dan Keselamatan Transportasi,2(2), 128-
140.

https://doi.org/10.46509/ajtk.v2i2.116

Muhammad Sholikhun. (2018). Pembentukan Karakter Siswa Dengan Sistem Boarding School. Jurnal Studi Keislaman Vol. 4 No.1 April 2018 hal. 49-64.

Lexy J. Moleong. (2012). Metodologi Penelitian Kualitatif. Bandung: PT. Remaja Rosdakarya.

M. Djamal. (2015). Paradigma Penelitian Kualitatif. Yogyakarta: Pustaka Pelajar.

Octavia, L dkk. (2014). Pendidikan Karakter Berbasis Tradisi Pesantren. Jakarta: Rumah Kitab.

Rachmat Kriyantono. (2006). Teknik Praktis Riset Komunikasi. Jakarta: Prenada Media Group. 